\title{
MARKET REACTIONS TO CSR NEWS IN DIFFERENT INDUSTRIES
}

\section{$\underline{\text { Structured abstract }}$}

Purpose - Based on the premises of the institutional theory, in this paper we explore the effects that media coverage of positive and negative Corporate Social Responsibility (CSR) news have on the stock market value of companies in diverse industries.

Design/methodology/approach - Using a sample of 195 online articles published in the most important Spanish business newspaper, we implement an event study and a regression analysis.

Findings - The findings show that positive and negative CSR news usually have significant impacts on the stock market value of companies. Specifically, the market reaction is stronger under the announcement of negative news in all industries (i.e., basic, energy, finance and goods and services) although positive news also cause significant positive stock market reactions in the finance and basic industries.

Originality/value - Although the media plays an indispensable role in the dialogue around CSR, much of the research focused on the role of the media on the CSR-CFP link does not consider how the industry variable can affect the abnormal stock returns derived from CSR news. This research contributes to this gap in literature by exploring the differences that exist in the stock market reactions to CSR news based on the industry in which the companies operate.

$\underline{\text { Keywords }}$ - Corporate social responsibility, financial performance, market value, media, industry

$\underline{\text { Article classification }}$ - Research paper 


\section{Introduction}

Corporate Social Responsibility (CSR) has received considerable scholarly attention over the decades, becoming an integral part of business practice (Casado-Díaz et al., 2014). One primary reason for its relevance in academic and business settings relates to the positive effects of CSR on the financial performance of companies (CFP), especially when CFP is evaluated through market-based measures (Casado-Díaz et al., 2014; Clacher and Hagendorff, 2012; Flammer, 2013; López-Arceiz et al., 2018; Verbeeten et al., 2016).

Under this premise, scholars have paid a special attention to the role of the media in the generation of stock market value based on the CSR action plans of companies (Gregory et al., 2014; Li et al., 2017; Tang, 2012; Zhang and Swanson, 2006). Media play an indispensable role in the dialogue around CSR due to three main reasons. First, media can be a channel through which companies communicate their commitment to CSR to the public to reduce information asymmetry (Feng et al., 2018). Second, media can also function as an independent monitor of companies' practices that safeguards the interests of their stakeholders (Cormier et al., 2011; Dhaliwal et al., 2011). Third, media can be a stakeholder that actively participates in the negotiation of CSR (Tang, 2012).

Along this line, previous research has demonstrated that large media coverage of CSR news has significant impacts on the generation of abnormal returns for companies in such a way that positive coverage leads to positive abnormal responses and negative coverage has just the opposite effect (Flammer, 2013; Gregory et al., 2014; Klassen and McLaughlin, 1996; Shane and Spicer, 1983). For instance, the day that Martin Winterkorn, President of the Administration Counsel of the German Volkswagen, publicly admitted that the company had falsified data on the emission of pollutant gases from its cars in the US, Volkswagen's share price fell $32 \%$ in the Dow Jones 
Sustainability World Index (DJSI World). The total drop of Volkswagen's share price in 2015 was finally estimated in $18.2 \%$. The consequences of the scandal for the company also included its removal from the DJSI World almost immediately after the publication of the news. Other companies in the automotive industry were also affected by the emissions scandal, such as Mitsubishi, which drop 15\% in the Tokyo Stock Exchange in April 2016, when the international press echoed the news.

Nevertheless, much of the research that exists on the role of media on the CSR-CFP link does not consider the influence of related variables that might affect the abnormal stock returns for companies (Casado-Díaz et al., 2014). In this regard, there have been claims to introduce more variables that relate to industry, culture, national systems and context into this line of research. More specifically, Halme and Laurila (2009) argued that the CFP outcomes of responsible corporate behavior might vary depending on firm-specific and industry-related factors.

In this paper, we argue that industry is one key factor that affects the CSR-CFP link explored in previous academic literature. In this regard, institutional theory (Deegan, 2002) argues that different industries are subject to specific and localized pressures from different stakeholders in such a way that industry might play a significant role in the relationship between CSR news and stock market value (Pérez et al., 2015). For example, banking and financial companies do not produce hazardous chemicals or discharge toxic pollutants into the air, land or water. Thus, they usually produce very little news related to environmental CSR actions because they do not suffer great stakeholder pressures to respond to specific environmental threats. According to institutional theory, then, environmental news would not be salient enough for banking investors because they are not expected to produce a direct response from stakeholders and, consequently, they will not affect future cash flows for the company significantly. On the contrary, polluting 
industries (e.g., basic resources, chemicals, automobile, and construction) have a larger impact on the environment (Gamerschlag et al., 2011) and issues related to this dimension may result in a larger media coverage and, consequently, more visibility (Patten, 1991). Visibility increases stakeholder pressure for the company to respond to the environmental threat and, thus, the way the company responds to this pressure may be expected to have a larger impact on the market value of companies in this industry. Nonetheless, this idea has not been sufficiently explored in previous research, and this fact contributes to the originality of the present paper.

Based on these ideas, the goal of this research is to explore whether the coverage of CSR news in the media has a different effect among companies from different industries in terms of the abnormal returns that they obtain in the stock market. For this purpose, we base our argument on the institutional theory, which provides the foundations to expect significant differences on the influence of CSR news on the stock market value of companies that suffer from diverse pressures and demands from their stakeholders. In identifying whether and how investors respond differently to CSR news depending on the industry variable, our paper aims to be useful to both researchers and practitioners. On the one hand, future researchers who aim to deepen the knowledge on the CSR-CFP link will be able to integrate institutional theory into their conceptual frameworks. In doing so, our paper can help them in transferring from generally theorizing on the effects of CSR news on market value to more specifically arguing differences in the intensity and significance of media's coverage of CSR news among diverse industrial contexts. On the other hand, corporate practitioners will be able to design CSR and public relations programs that are more effective because they will have further knowledge on how to maximize the positive impacts while neutralizing the negative effects of CSR news in their market value. 
The remainder of the paper is structured as follows. First, we review the existing literature on the media coverage of CSR news and its impact on the abnormal returns for companies in the stock market. Second, we discuss the role that industry might play in the CSR-CFP link explored in the paper. This literature review leads to the proposal of two research hypotheses that are explored through an empirical study of the stock price changes among companies listed in the Spanish Stock Market in 2015. Third, the method is described by paying especial attention to the research design and the sample of news used in the study. Fourth, the research findings are presented and discussed. Finally, we summarize the most relevant conclusions, managerial implications, limitations and future lines of research derived from the study.

\section{Literature review}

\subsection{Impact of media coverage of CSR news on CFP}

Most research on the linkage between firm-level CSR and financial performance (CFP) have found a positive correlation (Byun and Oh, 2018; Clacher and Hagendorff, 2012; Connors et al., 2013). This result can be explained theoretically because, although the cost of implementing CSR actions can be significant, these initiatives also generate other management benefits and revenues, while other type of corporate costs are reduced (Feng et al., 2018). For instance, CSR leads companies to higher morale of employees, attracts and retains quality employees, and improves consumers' attitude towards the company and its products (El Ghoul et al., 2017; Godos-Díez et al., 2014). Furthermore, investors have reported CSR considerations to be an important factor in their investment decisions, because they appreciate all the opportunities and rewards that a good CSR reputation brings to companies (Flammer, 2013; Tang, 2012). These ideas are the base of the marketbased measures of CFP, such as price per share or share price appreciation, which reflect 
investors' investment decisions based on cues and perceptions of past, current and future stock returns that determine the company's ability to strengthen its brand equity and generate future cash flows (Casado-Díaz et al., 2014).

Considering this perspective, scholars have long highlighted the influence of media news on investors' investment decisions (Clacher and Hagendorff, 2012; Connors et al., 2013; Flammer, 2013; Tang, 2012). According to institutional theory, media coverage of CSR news raises corporate visibility, inviting further public attention and scrutiny (Greening and Gray, 1994). Therefore, the media play a role in conforming or eroding the legitimacy of companies, influencing corporate reputation and, in doing so, exerting pressure for companies to improve their behavior in accordance to stakeholder expectations and demands. Media are non-corporate communication channels, generally perceived as more credible than corporate sources because of their unbiased nature (Skard and Thorbjørnsen, 2014). Media affect the stock market because they disseminate information to a broad audience, especially to individual investors (Wei et al., 2013). Positive news help materialize the goal of CSR, and they influence the reputation of companies significantly and positively (Zhang and Swanson, 2006). However, media are independent and noncontrolled sources, so the coverage is not always favorable for the company interests. If editors report on negative events, managers face a challenge because this news can cause a strong damage to the companies' record of CSR performance.

Specifically, previous research has shown that positive and negative news affect market reactions differently (Curran and Moran, 2007; Flammer, 2013; Patten, 2008; Wright et al., 1995). For example, Patten (2008) found that there is a significant market reaction in response to corporate press releases announcing charitable giving, specifically contributions to tsunami relief efforts. Wright et al. (1995) and Flammer (2013) analyzed reactions to positive and negative CSR news and found that announcements of companies 
receiving awards for voluntary affirmative CSR programs and eco-friendly corporate actions, respectively, are associated with significant and positive stock price changes for those companies. On the opposite, announcements of discriminatory practices and ecoharmful corporate events are associated with significant and negative stock returns. Based on these evidences, we propose that:

H1: Media coverage of CSR news affect the market value of a company. More specifically, positive CSR news will generate abnormal positive returns for the company, and conversely, negative CSR news will generate abnormal negative returns.

\subsection{Media coverage effects on the CFP of companies in diverse industries}

However, the limited approach of the previous works that have explored the CSR-CFP link in the academic literature is worth mentioning, since they have explored the hypothesis $\mathrm{H} 1$ only in a generic way, that is, without considering the possibility that industry was a key factor biasing their findings (Casado-Díaz et al., 2014; Klassen and McLaughlin, 1996). For example, Casado-Díaz et al. (2014) highlight that studies on CSR news have mostly focused on the product-based industry rather than the service industry. Nevertheless, in their paper, these authors demonstrate that CSR news have a positive impact on CFP that is higher for service companies than for manufacturing companies, especially when analyzing environment, responsible labor relationships and good corporate governance, which are especially important practices in the service context. Similarly, Klassen and McLaughlin (1996) observe that first-time environmental award announcements are associated with greater increases in market value, although smaller increases are observed for companies in environmentally dirty industries, possibly indicative of market skepticism. 
The relevance of the industry variable to explain investors' reactions to CSR news can be explained under the light of the institutional theory (Deegan, 2002; Patten, 2002). This theory proposes that stakeholders usually have different expectations concerning companies' CSR actions depending on the contexts where these companies operate (Pérez et al., 2015). A company's specific context differ from the context of other companies because of a variety of longstanding, historically entrenched institutions, which mean not only the formal organization of government and corporations but also norms, incentives, and rules within each national or industrial context (Campbell, 2007). Institutions are defined as stable, valued, recurring patterns of behavior characterized by their adaptability, complexity, autonomy, and coherence or as collections of rules and routines that define actions in terms of relations between roles and situations (Ostrom et al., 1991). In this regard, institutions enable predictable and patterned interactions that are stable, constrain individual behavior, and are associated with shared values and meaning among the society (Peters, 2011).

The CSR norms institutionalized in a society, which define the companies' contexts on it, frequently differ among industries (Campbell, 2007). For instance, scholars have frequently differentiated two types of industries: high- and low-profile industries (Hackston and Milne, 1996; Patten, 1991). As opposed to low-profile industries, highprofile industries face greater stakeholder pressures, a high level of political risk and concentrated intense competition (Roberts, 1992). Thus, companies in high-profile industries are exposed to higher political visibility and media exposure. In this context, high-profile companies have numerous incentives to use CSR to influence their political visibility and reduce public pressures (Ghazali, 2007). Aligning with this perspective, Patten (1991) argues that industry influences political visibility and this drives CSR actions to ward off undue pressure and criticism from social activists. As a consequence, 
high-profile companies feel the need to project positive CSR identities and as so they report significantly more CSR information than low-profile companies (Hackston and Milne, 1996), which do not suffer from high stakeholder pressures to behave ethically or in accordance to normative CSR principles (Ghazali, 2007).

Although classifications are to an extent subjective and ad-hoc, most scholars identify companies in basic industries (e.g., petroleum, chemical, forest and paper) and energy companies as high profile. In this paper, we also include finance as a high-profile industry, in accordance with the proposal of Pérez et al. (2015). As argued by these scholars, the finance industry has recently attracted great media coverage because of the economic recession that has especially threatened this industry. This circumstance generates new forms of coercive pressures in exchange for continued legitimacy and can take finance companies to increase their use of CSR.

Overall, and based on institutional theory, we expect that CSR news that discuss corporate behaviour on specific industries where companies feel high pressures will be especially appreciated by investors because these pieces of news deal with relevant information that anticipates future responses from stakeholders and, therefore, future cash-flows for the company. This being so, we can expect that investors are more demanding in high- than low-profile industries, which would justify a stronger impact of CSR news on the abnormal returns for these companies in the stock market. Thus, we propose the second hypothesis of the paper, which reads as follows:

H2: The importance of media coverage of CSR news varies across industries. More specifically, media coverage of CSR news has a stronger impact on a company's abnormal returns for high-profile industries (i.e., basic, energy and finance) than low-profile industries (i.e., consumer goods and services). 


\section{Data and sample}

\subsection{Data collection}

The identification of CSR news was made by examining the online database of the newspaper "Expansión", which allowed us to identify media's coverage of CSR from January 1 to December 31, 2015. We selected "Expansión" because this was the leading business newspaper in Spain according to their audience and diffusion volumes in 2015 (OJD, 2019).

To identify the pieces of CSR news, we implemented a content analysis of the online database by using the list of CSR topics proposed by Pérez et al. (2015). As explained by these scholars, all the topics had been taken from previous papers that had attempted to evaluate CSR in different industries (Bird et al., 2007; Brammer and Pavelin, 2004, 2006; Clarkson, 1995; de los Ríos et al., 2012; Maignan and Ferrell, 2004; Melo and GarridoMorgado, 2012; Michelon, 2011; Michelon et al., 2013; Mishra and Suar, 2010; Soppe et al., 2011; Turker, 2009). The topics were also classified in eight dimensions based on Fombrun et al.'s (2000) categorization of stakeholders: community, customers, investors, employees, regulators, partners, activists and media (Pérez et al., 2015). This selection of stakeholders included primary and secondary stakeholders as well as stakeholders with voting, economic and political power (Kent and Chan, 2005; Pérez et al., 2017). The community dimension contained CSR topics related to general social, environmental and economic concerns (Bird et al., 2007; Brammer and Pavelin, 2004; Maignan and Ferrell, 2004; Melo and Garrido-Morgado, 2012; Michelon, 2011; Mishra and Suar, 2010). The customer dimension contained CSR topics related to the company's commercial offering and marketing practices (Bird et al., 2007; de los Ríos et al., 2012; Maignan and Ferrell, 2004; Melo and Garrido-Morgado, 2012; Michelon, 2011; Mishra and Suar, 2010; Soppe et al., 2011). The investor dimension consisted of CSR topics concerning the ethical 
relationship of the company with its investors and shareholders (Mishra and Suar, 2010). The employee dimension included CSR topics that evaluated information mostly referring to working conditions and fair treatment of employees (Bird et al., 2007; Brammer and Pavelin, 2004; Maignan and Ferrell, 2004; Melo and Garrido-Morgado, 2012). The regulator dimension included CSR topics referring to the compliance with laws and regulations (Mishra and Suar, 2010; Soppe et al., 2011). The partner dimension included CSR topics that evaluated how the company promoted CSR along the supply chain (Mishra and Suar, 2010). The activist dimension consisted of CSR topics related to the partnership of the company with other organizations devoted to CSR causes (Maignan and Ferrell, 2004; Mishra and Suar, 2010). Finally, the media dimension included CSR topics that covered the management of relationships with the media. Additional information regarding the full list of CSR topics and their classification in dimensions is provided in the appendix.

To perform the content analysis, we contacted two experienced coders to explore the content of each piece of CSR news independently, following the procedure suggested by Bravo et al. (2012). The coders were research fellows contacted ad hoc for the study and they received training and supervision from the authors during the coding process. More precisely, the coders were explained the purposes of the research, and then performed an initial examination of some CSR news in collaboration with the authors. A meeting was scheduled to discuss the most relevant incidents and obtain consensus on the analytic criteria. Subsequently, regular meetings to discuss new incidents and refine the criteria were arranged. In the end, each piece of CSR news was analysed by the two coders independently and the intercoder agreement coefficients, which measure the coding relability, were calculated according to the procedure suggested by Perreault and Leigh (1989). For each dimension and CSR topic, this procedure reported levels of accordance 
in the evaluation noticeable above the minimum recommended value of $80 \%$, which is acceptable for this type of method and similar to previous literature (Tang, 2012).

The initial pool of CSR news identified for the study included 252 articles. These dimensions included the community (70), customer (63), investor (54), employee (44), regulator (12) and partner (9) CSR news. No pieces of news were identified in the CSR dimensions related to activists and the media.

Nevertheless, during the coding process some filters were applied. First, CSR news related to regulators and partners were scarce in 2015. The inclusion of these two dimensions in the empirical analyses could represent problems in terms of the reliability and robustness of the findings presented in the paper because the articles collected were not sufficiently varied to guarantee representativeness of each dimension. Therefore, we decided to proceed only with the dimensions in which sufficient and varied pieces of CSR news were coded. Second, because each dimension was compounded of a large number of CSR topics, some of these topics were underrepresented in our initial sample of CSR news. In these cases, we decided to aggregate the topics where little number of articles were identified to create larger categories of CSR news. In many cases, they were aggregated under a general CSR topic labelled as "Other". Third, in our initial database we found various news that were concerned with the same CSR story, although they were published at different times of the year. In these cases, we only retained the first article that referred to each specific CSR story to capture the first market reaction exclusively. Finally, we also checked that there were not related news about each company during the event window to avoid bias in the results due to the presence of contaminating events in the same period. After the application of these filters, the final sample contained 195 CSR news. 
For each piece of CSR news that we retained we identified the following information: (1) event date, (2) name of the company, (3) industry, (4) CSR dimension, (5) CSR topic and (6) positive/negative overall assesment. Positive news identified articles reflecting cohesion, co-operation, stability and corporate strength. Negative news reflected conflicts, disorganization, instability and weaknesses of the company (Zhang and Swanson, 2006). An illustration of the codification procedure followed in this paper to classify positive and negative news is presented in the appendix.

\subsection{Characterization of news, companies and industries}

The 195 articles identified for the study were distributed as follows: basic industry $(n=26$, $13.30 \%, 11$ companies), energy ( $n=41,21.00 \%, 8$ companies $)$, finance ( $n=91,46.70 \%, 8$ companies) and goods and services ( $\mathrm{n}=37,19.00 \%, 10$ companies). We also found that some companies attracted more media attention than others, especially banks. For example, more than 15 articles focused on CSR news related to some of the largest banks in Spain (i.e., Bankia, Santander Bank, Caixabank and BBVA). Only two other nonfinancial companies attracted as much media attention as banks. That was the case of Iberdrola, and Telefónica, from the energy and goods and services industries respectively. Thus, our sample suggests that finance was the most visible industry in the Spanish media's coverage of CSR in 2015, which is explained by the high-profile of this industry in the country, derived from its high involvement in the latest international recession (Pérez et al., 2015). Similarly, the energy and basic industries are also high-profile and are traditionally targeted by the media (Pérez et al., 2015). Additionally, the size of the companies can also explained its relevance in the news, since these 6 companies are in the Top 20 of the largest companies in the Spanish Stock Market according to their capitalization (BME, 2015). 
Table 1 presents a summary of the CSR news contained in the final sample, classified according to the dimension, topic, positive/negative assessment and industry in which they were classified by the coders.

\section{Insert Table 1 about here}

\section{Method and findings}

\subsection{Event study: Market reaction to CSR news}

We employed an event study methodology to analyze the market reaction to CSR news. This method allows assessing the financial impact of a specific event, by determining whether there is an 'abnormal' stock price effect associated with an unanticipated event (McWilliams and Siegel, 1997). The event study method allows measuring the effect of an unanticipated event on stock prices, and is based on estimating a market model for each company and then calculating abnormal returns, which are assumed to reflect the stock market's reaction to the arrival of new information.

We estimated a market model with daily returns and calculated the abnormal returns, defined as the difference between the return actually obtained on a given day and the expected return according to a market model previously estimated. That is, the rate of return of the stock is adjusted by subtracting the expected return from the actual return, and any significant difference is considered an abnormal return.

The estimation period used to estimate the market model lasted 250 days, from 270 days to 21 days before the event date (i.e., date of appearance of the CSR news in the newspaper). We took 21 days before the announcement to avoid that the model estimation was influenced by the event itself.

Once the abnormal returns are calculated, we needed to define the period over which the prices would be examined, called the event window. We defined an event window larger than the specific day of the publication of the news, which allowed examining periods 
surrounding the specific event (MacKinlay, 1997). So, abnormal returns were calculated over the event window around the event date. Cumulative abnormal returns were averaged over different event windows to include possible reactions in the share prices before and after the event, since the periods prior to and after the event may also be of interest in this type of studies (MacKinlay, 1997). In particular, we considered a long period of 11 days around the event date $([-5,+5])$, and some shorter windows immediately around the announcement $([-1,0],[0],[0 ;+1],[-1,+1])$. This variable length of the event window allowed us to control for possible leaks or rumors that could advance the reaction of the market at the date of the announcement, or the publication on a day when the market was closed (McWilliams and Siegel 1997). In addition to this, by using windows of variable duration we can avoid the bias that an inaccurate delimitation of the event window could produce.

To test if the event had a significant impact on the market value of the company, the statistic based on normalized excess returns was used (Dodd and Warner, 1983). If the cumulative abnormal return is significant, it measures the average effect of the event on the value of the companies. Finally, to compare the reaction among industries we used the Wilcoxon rank-sum, which allowed us to test the statistical differences in the cumulative abnormal returns produced in each industry.

The results of the event study are presented in Table 2, distinguishing between the CSR news that were expected to have a positive and a negative effect on the market value of companies. For each event window considered in the study, Table 2 includes the average cumulative abnormal return (ACAR) and the test of statistical significance (Dodd and Warner, 1983). In addition to this, to test the differences in the magnitude of the reaction, we present the Wilcoxon rank-sum test. Since we had positive and negative reactions, we applied the test comparing the absolute value of returns. 


\section{Insert Table 2 about here}

The findings indicate the existence of statistically significant abnormal returns in the days around the event date, for both positive and negative CSR news. On the one hand, media coverage of companies' positive CSR news generated significant and positive abnormal returns for those companies. On the other hand, negative coverage generated significant and negative returns for the companies under scrutiny. Thus, the hypothesis H1 was confirmed by the findings of our study. In both cases, the largest market reaction $(0.51 \%$ and $-2.75 \%$ for positive and negative CSR news respectively) appeared in the window [$1,+1]$. The analysis also showed that significant reactions only occurred within a 3-day window around the event date, while reactions became non-significant when a longer event window $([-5,+5])$ was considered. Therefore, the findings of the study confirm that the market reacted very quickly to the release of CSR news, although the effect was diluted over the longer term.

\subsection{Regression analysis: Market reaction to CSR news in different industries}

We undertook an ordinary least squares (OLS) regression using the abnormal return in the window $[-1,+1]$ to determine if significant differences existed in the market reaction to CSR news in different industries. We used the White correction to control for the heteroscedasticity that usually appears in cross-section analyses. The proposed model was:

$C A R=\left(\alpha_{1}+\varphi_{1} S I G\right) B A S+\left(\alpha_{2}+\varphi_{2} S I G\right) E N E R+\left(\alpha_{3}+\varphi_{3} S I G\right) F I N A N C+\left(\alpha_{4}+\right.$ $\left.\varphi_{4} S I G\right) G S E R+\left(\alpha_{5}+\varphi_{5} S I G\right) S A L E S+\left(\alpha_{6}+\varphi_{6} S I G\right) R O E+\left(\alpha_{7}+\varphi_{7} S I G\right) P D C T+\varepsilon$ The dependent variable (CAR) was the cumulative abnormal return in the window [-1; +1 ]. We also defined dummy variables, included as explanatory variables in the model, to study the differences in the market reaction according to each industry. For each industry, we defined a variable that took the value one for CSR news related to that 
specific industry and zero otherwise. Our sample contained companies of four different industries: basic (BAS), energy (ENER), finance (FINANC), goods and services (GSER). In order to reduce bias in the results, control variables were also included in the analysis. Specifically, we introduced corporate size (SALES), measured as the log of the sales of the company (Zhang et al., 2014); corporate financial performance (ROE), measured by the return on equity (Clacher and Hagendorff, 2012); and employee productivity (PDCT), measured by the ratio of EBIT to number of employees (Clacher and Hagendorff, 2012). It is also important to notice that CARs in the analysis were expected to be either positive or negative. Thus, to control for their asymmetric effect in the empirical analysis, we defined a dummy variable (SIG) that took the value one for the CSR news that we expected to be positive and zero for the CSR news that were expected to be negative. To study the effect of each variable in the event of positive and negative returns, all the variables were included in the model specification interacting with the dummy SIG. The inclusion of these interacted variables allowed us to test the research hypotheses by interpreting both the individual and the interaction coefficients. For example, in the case of the CSR news related to companies in the basic industry, we interpreted the coefficient $\alpha_{1}$ and the sum of coefficients $\alpha_{1}+\varphi_{1}$. If the coefficient $\alpha_{1}$ was statistically different from zero, it indicated the sensitivity of the CAR to the negative news about companies in the basic industry (when SIG was equal to zero). To interpret the interaction variables correctly, it was also necessary to perform a linear restriction test. In this regard, and following the same example of the basic industry companies, if the sum of coefficients $\alpha_{1}+\varphi_{1}$ was statistically different from zero, it captured the sensitivity of the CAR to the positive news related to companies in the basic industry (when SIG was equal to one). For all the variables, we followed the same pattern: the individual coefficients $\left(\alpha_{1} ; \alpha_{2} ; \alpha_{3} ; \alpha_{4} ; \alpha_{5} ; \alpha_{6} ; \alpha_{7}\right)$ measured the sensitivity of the CAR to negative news, while 
the sum of coefficients $\left(\alpha_{1}+\varphi_{1} ; \alpha_{2}+\varphi_{2} ; \alpha_{3}+\varphi_{3} ; \alpha_{4}+\varphi_{4} ; \alpha_{5}+\varphi_{5} ; \alpha_{6}+\varphi_{6} ; \alpha_{7}+\right.$ $\left.\varphi_{7}\right)$ measured the sensitivity of the CAR to positive news. In all cases, the standardized coefficients of the variables were calculated and interpreted.

Table 3 shows the results of the regression analysis.

\section{Insert Table 3 about here}

Concerning the CSR news that were expected to generate positive market reactions, we found direct effects of the CSR news of companies in the basic industry $(\alpha 1+\varphi 1=0.04$, $\mathrm{p}<0.10)$ and the finance industry $(\alpha 2+\varphi 2=0.04, \mathrm{p}<0.1)$. In both cases, the sum of the coefficients were positive and significant. Thus, positive CSR news in these industries provoked positive market reactions. According to the standardized coefficients, the CSR news in the finance industry caused greater positive abnormal returns $(B e t a=0.58)$ than in the basic industry $(B e t a=0.24)$. We did not find evidence of any market reaction to positive news in the energy and the good and services industries.

As far as negative CSR news are concerned, we also found direct relationships, this time in the four industries analyzed in the study. Specifically, we found direct effects of the CSR news of companies in the basic $(\alpha 1=-0.17, \mathrm{p}<0.01)$, energy $(\alpha 2=-0.32, \mathrm{p}<0.01)$, finance $(\alpha 3=-0.17, \mathrm{p}<0.05)$ and good and services industries $(\alpha 4=-0.18, \mathrm{p}<0.05)$. These findings confirm that the announcement of CSR news with negative content in these four industries provoked a negative reaction in the share prices of the companies, since all the coefficients were negative and significant. However, according to the standardized coefficients, the CSR news in the energy industry caused the greatest negative abnormal returns $($ Beta $=-4.05)$, followed by the news of the finance industry (Beta=-2.67), the good and services industry (Beta=-2.18) and the basic industry (Beta=-1.77). It was also observed that corporate size and employee productivity were significant in reducing the negative market reaction to the announcement of negative CSR news. Specifically, the 
magnitude of the negative market reaction was smaller for bigger companies $(\alpha 5=0.01$, $\mathrm{p}<0.05)$ and for the companies that had more employee productivity $(\alpha 7=0.00, \mathrm{p}<0.05)$. When compared to positive news, we also observed that the market reaction was stronger under the announcements of negative news in all the industries analyzed in this research. In the case of the basis and the finance industries, Table 3 shows that the standardized coefficients were smaller in the case of positive CSR news in both industries. This difference is even stronger for energy and goods and services industries, where we did not even find any market reaction for positive news. In this regard, none of the companies' specific control variables analyzed in the paper had any significant effect in the model when positive CSR news were explored.

Overall, the findings of the regression analysis allowed us to confirm the second hypothesis of our paper $(\mathrm{H} 2)$, although only partially. More precisely, the findings showed that, indeed, the importance of CSR media coverage varies across industries, since the market reaction is different in each industry considered. In addition, in the case of negative news we found a stronger impact on significant abnormal returns for companies in the energy and finance industries (high-profile industries) than for companies in the goods and services industry (low-profile industry). However, we found that a significantly smaller reaction appeared for companies in the basic industry, which is also considered a high-profile industry. In the case of positive news, we only found a significant market reaction for companies in high-profile industries (finance and basic industries), while for goods and services companies the findings did not confirm any significant reaction. We could not find significant market reactions to positive news in the energy industry either, although this is considered a high-profile industry. Thus, we cannot conclude that CSR news generate greater impacts in the market value of companies in all high-profile industries, as we had previously hypothesized in our paper. 


\section{Discussion and conclusions}

Based on the principles of the institutional theory, this research has explored the relationship that exists between media coverage of corporate social responsibility (CSR) and corporate financial performance (CFP) along with the role that industry plays in the CSR-CFP link.

As far as the first research hypothesis (H1) is concerned, the findings of the study confirm the relevance of media coverage of CSR news to satisfy corporate financial goals. This idea has been previously suggested in academic literature (Patten, 2008; Zhang et al., 2014) when scholars have defended that media's coverage of CSR news sets the CSR agenda for companies by disseminating information (Zhang and Swanson, 2006), raising public awareness about CSR topics (Wei et al., 2013) and selectively emphasizing them (Tang, 2012). More precisely, the empirical study undertaken in this research demonstrates that while positive news usually have a positive impact on the abnormal returns experienced by companies, news including negative connotations always have a negative effect on these market reactions.

What is more, investors usually react more strongly to the announcement of corporate CSR actions that have negative (vs. positive) implications for their stakeholders. As previously defended in academic literature, irresponsible corporate actions result in substantial decreases in investors' wealth that are difficult to recover despite the announcement of positive CSR news (Curran and Moran, 2007). In this regard, research has revealed that people often give negative news more weight than positive news (Ahluwalia et al., 2000) because they perceive negative information as more useful information for categorizing targets (i.e., companies, news, etc) into evaluative categories (Herr et al., 1991). Therefore, negative news frequently receives greater weight in overall 
corporate assessment (Wang, 2008). This finding relates to the framing effect, which works through an accessibility-driven process (Wang, 2008). More precisely, framing consists of selecting some aspects of a perceived reality and making them more salient in a communicating text, in such a way as to promote a particular problem definition, causal interpretation or moral judgment (Cappella and Jamieson, 1997; Wang, 2007). When a particular subject is framed, the subject becomes more accessible and thus more likely to play a role in the formation of attitude and subsequent judgments. In this context, people may consider negative news about a company's CSR as an important piece of information to assess a company's CSR actions because of two processes. First, a concern to be accurate is likely to attenuate the biasing effects of personal factors, thereby heightening the importance of negative news (Chaiken et al., 1996). Secondly, as social concerns such as assessing a company's CSR actions increase, people tend to become more risk averse, focusing their attention on negative news (Maheswaran and Meyers-Levy, 1990) and thereby using it as the basis of their assessments of the company's CSR actions (Wang, 2007). Thus, companies must be extremely careful with the way they manage their corporate crises and their public relations function when dealing with the media. By deciding how to deal with the news, the media can always magnify or limit the damage caused by corporate scandals in such a way that a cordial relationship with them becomes extremely important for the successful management of CSR issues. Managing variables such as corporate size and employee productivity may also help companies to neutralize the negative effects of negative media's coverage of CSR news.

In addition to these findings, this research show that the most intense effect of CSR news on the abnormal returns for companies occurs in the 3-day timeframe $([-1,+1])$, while it diminishes over time and it becomes insignificant when longer timeframes are considered (e.g., $[-5,+5])$. This finding is consistent with the results reported by previous scholars, 
such as Shane and Spicer (1983), who show that the average abnormal returns aggregated for the dates around the release of the first environmental report of a company are much larger than for the following days and even reports.

Concerning the second research hypothesis (H2), the findings of the study confirm that most of the ideas previously discussed in this section are applicable to almost any industry for which market reactions to CSR news are analyzed. For instance, negative CSR news have significant negative impacts on the market value of any company, regardless of whether it is in the energy, basic, finance or goods and services industry. On the contrary, positive CSR news only have significant positive impacts on the market value of finance and basic companies, although the strength of the market reaction is still less than for negative news.

Nevertheless, the findings of the study allow us to accept $\mathrm{H} 2$ only partially as they do not confirm that all companies in high profile industries accumulate a stronger impact of CSR news on their abnormal returns in the stock market when compared to low-profile industries.

Among high-profile industries, the finance industry is presented as the only context where the institutional theory rules seem to apply (Deegan, 2002). In this regard, the finance industry is currently facing a serious trust crisis closely related to the latest economic recession in Spain (started in 2008). Crises create a form of institutional pressure, which reflects societal ills, poses threats to organizational and governmental legitimacy, and generates institutional pressures from stakeholders. Thus, the crisis has taken the finance industry to be highly visible and political costs have significantly risen in this context. These circumstances generate demands for accountability that translate into new forms of coercive pressure in exchange for continued legitimacy (Ghazali, 2007). In this paper, the detailed analysis of the composition of the news sample shows that large companies 
in the finance industry attract more media attention in the CSR context than smaller companies in other industries, in such a way that media coverage is playing a significant role in increasing the stakeholder pressures faced by companies.

As for the case of the basic industry, investors also react positively to positive news and negatively to negative news but, as far as the negative reaction is concerned, this response is not as intense as for good and services companies, which are included in a low-profile industry. Although the basic industry has traditionally suffered from strong social pressures derived from their visibility, political risk and intense competition (Gamerschlag et al., 2011), investors and society have also increased their pressure over the good and services industry to incorporate social and environmental considerations in their business activities (Pérez et al., 2015). For example, retailers are frequently criticized by various stakeholders because of their increasing economic weight and the importance of the externalities generated by their actions on society and the environment (Mejri and de Wolf, 2012). Furthermore, good and services companies are very large and the most capital intensive in the economy, and as so they tend to interface with the most extensive array of stakeholder groups to whom they have to be responsive (Jones, 1999). All these circunstances increase investors' risk aversion that lead to especially negative responses to negative CSR news.

Also similar to the case of the good and services industry, the findings regarding the energy industry show that investors are especially sensitive to negative news, while they do not react in a special way to the announcement of positive CSR actions in the media. This finding may be explained by the fact that most of the negative news reported by the media concerning the energy industry refer to records of employment regulation (RERs) that significantly threaten the continuity of companies and, therefore, are highly penalized by investors who are evaluating where to invest their money. 
These findings have significant implications for the management of CSR and media relations in companies. First, companies should apply a long-term strategic approach to CSR because it does have an important effect on their market value. Second, we would also like to highlight the relevance of the public relations function of the company to manage its relationships with the media. An adequate design of their public relations strategy would surely enhance the publicity of positive news while minimizing the negative impact of CSR crises. Third, implications are also observed for companies in different industries because interesting insights are provided regarding how companies can improve their visibility and power to attract investors in the financial market. One last important issue that CSR managers should take into account relates to the knowledge that the effect of CSR news is quite immediate, that is, news provoke a strong reaction in the investor's mind in the short time. Thus, companies should select the announcement day carefully to maximize its positive impact on their market value.

Finally, this study is not without limitations and future research should consider them to improve the knowledge on media coverage, CSR and CFP. In this regard, this study took only a snapshot view of media's stance on CSR in Spain because it only examined the content of a specialist business newspaper in the country. Therefore, the findings may not represent the full spectrum of CSR issues covered in Spanish media as there are other types of general newspapers that also cover CSR issues (general vs. specialist newspapers). Also, the study only covered articles published in a time frame of one year. This fact represents a relevant limitation of the study because it means that the findings are likely to be influenced by the specific economic, social or political situation of the country in the year of the analysis. Based on these limitations, future researchers should propose analyses that include a broader spectrum of media, countries and time frames that reduce the biases that may have been found in the present paper. 


\section{References}

Ahluwalia, R., Burnkrant, R.E. and Unnava, H.R. (2000), “Consumer response to negative publicity: The moderating role of commitment", Journal of Marketing Research, Vol. 37 No. 2, pp. 203-214.

Alexander, G.J. and Buchholz, R.A. (1978), “Corporate social responsibility and stock market performance", Academy of Management Journal, Vol. 21 No. 3, pp. 479486.

Berman, S.L., Wicks, A.C., Kotha, S. and Jones, T.M. (1999), "Does stakeholder orientation matter? The relationship between stakeholder management models and firm financial performance", Academy of Management Journal, Vol. 42 No. 5, pp. $488-506$.

Bird, R., Hall, A.D., Momentè, F. and Reggiani, F. (2007), "What corporate social responsibility activities are valued by the market?", Journal of Business Ethics, Vol. 76 No. 2, pp. 189-206.

BME. (2015), Informe Anual 2015, available at: http://www.bolsamadrid.es.

Brammer, S. and Pavelin, S. (2004), "Building a good reputation", European Management Journal, Vol. 22 No. 6, pp. 704-713.

Brammer, S.J. and Pavelin, S. (2006), “Corporate reputation adn social performance: The importance of fit", Journal of Management Studies, Vol. 43 No. 3, pp. 435456.

Bravo, R., Matute, J. and Pina, J.M. (2012), "Corporate social responsibility as a vehicle to reveal the corporate identity: A study focused on the websites of Spanish financial entities", Journal of Business Ethics, Vol. 107 No. 2, pp. 129-146.

Byun, S.K. and Oh, J.M. (2018), "Local corporate social responsibility, media coverage, 
and shareholder value", Journal of Banking and Finance, Elsevier B.V., Vol. 87, pp. 68-86.

Campbell, J.L. (2007), "Why would corporations behave in socially responsible ways? An institutional theory of corporate social responsibility", Academy of Management Review, Vol. 32 No. 3, pp. 946-967.

Cappella, J.A. and Jamieson, K.H. (1997), Spiral of Cynicism, Oxford University Press, New York, NY.

Casado-Díaz, A.B., Nicolau-Gonzálbez, J.L., Ruiz-Moreno, F. and Sellers-Rubio, R. (2014), "The differentiated effects of CSR actions in the service industry", Journal of Services Marketing, Vol. 28 No. 7, pp. 558-565.

Chaiken, S., Giner-Sorolla, R. and Chen, S. (1996), "Beyond accuracy: Defense and impression motives in heuristic and systematic information processing”, in Gollwitzer, P.M. and Bargh, J.A. (Eds.), The Psychology of Action: Linking Cognitiion and Motivation to Behavior, Guilford, New York, NY, pp. 553-578.

Clacher, I. and Hagendorff, J. (2012), "Do announcements about corporate social responsibility create or destroy shareholder wealth? Evidence from the UK", Journal of Business Ethics, Vol. 106 No. 3, pp. 253-266.

Clarkson, M.B.E. (1995), “A stakeholder framework for analyzing and evaluating corporate social performance", Academy of Management Review, Vol. 20 No. 1, pp. $92-117$.

Connors, E., Johnston, H.H. and Silva-Gao, L. (2013), “The informational value of Toxics Release Inventory performance”, Sustainability Accounting, Management and Policy Journal, Vol. 4 No. 1, pp. 32-55.

Cormier, D., Ledoux, M. and Magnan, M. (2011), "The informational contribution of social and environmental disclosures for investors", Management Decision, Vol. 
49 No. 8, pp. 1276-1304.

Curran, M.M. and Moran, D. (2007), "Impact of the FTSE4Good Index on firm price: An event study", Journal of Environmental Management, Vol. 82 No. 4, pp. 529537.

Deegan, C. (2002), "The legitimising effect of social and environmental disclosures - A theoretical foundation", Accounting, Auditing \& Accountability Journal, Vol. 15 No. 3, pp. 282-311.

Dhaliwal, D.S., Li, O.Z., Tsang, A. and Yang, Y.G. (2011), "Voluntary nonfinancial disclosure and the cost of equity capital: The initiation of corporate social responsibility reporting", Accounting Review, Vol. 86 No. 1, pp. 59-100.

Dodd, P. and Warner, J.B. (1983), “On corporate governance: A study of proxy contest”, Journal of Financial Economics, Vol. 11 No. 1-4, pp. 401-438.

Feng, Z.-Y., Chen, C.R. and Tseng, Y.J. (2018), "Do capital markets value corporate social responsibility? Evidence from seasoned equity offerings", Journal of Banking and Finance, Elsevier B.V., Vol. 94, pp. 54-74.

Flammer, C. (2013), “Corporate social responsibility and shareholder reaction: The environmental awareness of investors", Academy of Management Journal, Vol. 56 No. 3, pp. $758-781$.

Fombrun, C.J., Gardberg, N.A. and Sever, J.M. (2000), “The reputation quotientSM: A multi-stakeholder measure of corporate reputation", Journal of Brand Management, Vol. 7 No. 4, pp. 241-255.

Gamerschlag, R., Möller, K. and Verbeeten, F. (2011), “Determinants of voluntary CSR disclosure: Empirical evidence from Germany", Review of Managerial Science, Vol. 5 No. 2, pp. 233-262.

Ghazali, N.A.M. (2007), “Ownership structure and corporate social responsibility 
disclosure: Some Malaysian evidence”, Corporate Governance, Vol. 7 No. 3, pp. $251-266$.

El Ghoul, S., Guedhami, O. and Kim, Y. (2017), "Country-level institutions, firm value, and the role of Corporate Social Responsibility initiatives", Journal of International Business Studies, Vol. 48 No. 3, pp. 360-385.

Godos-Díez, J.L., Fernández-Gago, R., Cabeza-García, L. and Martínez-Campillo, A. (2014), "Determinants of CSR practices: Analysis of the influence of ownership and the management profile mediating effect", Spanish Journal of Finance and Accounting, Routledge, Vol. 43 No. 1, pp. 47-68.

Greening, D.W. and Gray, B. (1994), “Testing a model of organizational response to social and political issues", Academy of Management Journal, Vol. 37 No. 3, pp. $467-498$.

Gregory, A., Tharyan, R. and Whittaker, J. (2014), "Corporate Social Responsibility and firm value: Disaggregating the effects on cash flow, risk and growth", Journal of Business Ethics, Vol. 124 No. 4, pp. 633-657.

Guo, L. and Mech, T.S. (2000), "Conditional event studies, anticipation, and asymmetric information: The case of seasoned equity issues and pre-issue information releases", Journal of Empirical Finance, Vol. 7 No. 2, pp. 113-141.

Hackston, D. and Milne, M.J. (1996), "Some determinants of social and environmental disclosures in New Zealand companies", Accounting, Auditing \& Accountability Journal, Vol. 9 No. 1, pp. 77-108.

Halme, M. and Laurila, J. (2009), "Philanthropy, integration or innovation? Exploring the financial and societal outcomes of different types of corporate responsibility", Journal of Business Ethics, Vol. 84 No. 3, pp. 325-339.

Herr, P.M., Kardes, F.R. and Kim, J. (1991), "Effects of word-of-mouth and product- 
attribute information on persuasion: An accessibility-diagnosticity perspective", Journal of Consumer Research, Vol. 17 No. 4, pp. 454-462.

Jones, M.T. (1999), “The institutional determinants of social responsibility”, Journal of Business Ethics, Vol. 20 No. 2, pp. 163-179.

Kent, P. and Chan, C. (2005), "Application of stakeholder theory to the quantity and quality of Australian voluntary corporate environmental disclosures", SSRN Electronic Journal.

Klassen, R.D. and McLaughlin, C.P. (1996), “The impact of environmental management on firm performance", Management Science, Vol. 42 No. 8, pp. $1199-1214$.

Li, D., Xin, L., Chen, X. and Ren, S. (2017), “Corporate social responsibility, media attention and firm value: Empirical research on Chinese manufacturing firms", Quality and Quantity, Vol. 51 No. 4, pp. 1563-1577.

López-Arceiz, F.J., Bellostas-Pérezgrueso, A.J., Moneva-Abadía, J.M. and RiveraTorres, M.P. (2018), “The role of corporate governance and transparency in the generation of financial performance in socially responsible companies", Spanish Journal of Finance and Accounting, Vol. 47 No. 1, pp. 44-80.

de los Ríos, A., Ruiz, M., Tirado, P. and Carbonero, M. (2012), “Una aproximación a la relación entre información sobre la responsabilidad social orientada al cliente y la reputación corporativa de las entidades financieras españolas”, Cuadernos de Economia y Direccion de La Empresa, ACEDE, Vol. 15 No. 3, pp. 130-140. MacKinlay, A.C. (1997), "Event studies in economics and finance”, Journal of Economic Literature, Vol. 35 No. 1, pp. 13-39.

Maheswaran, D. and Meyers-Levy, J. (1990), "The influence of message framing and issue involvement”, Journal of Marketing Research, Vol. 27 No. 3, pp. 361-367. 
Maignan, I. and Ferrell, O.C. (2004), “Corporate social responsibility and marketing: An integrative framework", Journal of the Academy of Marketing Science, Vol. 32 No. 1, pp. 3-19.

McWilliams, A. and Siegel, D. (1997), "Event studies in management research: Theoretical and empirical issues", Academy of Management Journal, Vol. 40 No. 3, pp. 626-657.

Mejri, M. and de Wolf, D. (2012), “Analysis of retailers' communication approaches in sustainability and social responsibility reports", International Journal of Marketing Studies, Vol. 4 No. 2, pp. 30-44.

Melo, T. and Garrido-Morgado, Á. (2012), “Corporate reputation: A combination of social responsibility and industry", Corporate Social Responsibility and Environmental Management, Vol. 19 No. 1, pp. 11-31.

Michelon, G. (2011), "Sustainability disclosure and reputation: A comparative study", Corporate Reputation Review, Vol. 14 No. 2, pp. 79-96.

Michelon, G., Boesso, G. and Kumar, K. (2013), "Examining the link between strategic corporate social responsibility and company performance: An analysis of the best corporate citizens", Corporate Social Responsibility and Environmental Management, Vol. 20 No. 2, pp. 81-94.

Mishra, S. and Suar, D. (2010), Does Corporate Social Responsibility Influence Firm Performance of Indian Companies?, Journal of Business Ethics, Vol. 95. OJD. (2019), "Información y Control de Publicaciones (OJD) website", available at: http://www.introl.es.

Ostrom, E., March, J.G. and Olsen, J.P. (1991), Rediscovering Institutions: The Organizational Basis of Politics.

Patten, D.M. (1991), “Exposure, legitimacy, and social disclosure”, Journal of 
Accounting and Public Policy, Vol. 10 No. 4, pp. 297-308.

Patten, D.M. (1992), "Intra-industry disclosure in response to the Alaskan oil spill: A note on legitimacy theory”, Accounting, Organizations and Society, Vol. 17 No. 5, pp. $471-475$.

Patten, D.M. (2002), “Media exposure, public policy pressure, and environmental disclosure: An examination of the impact of tri data availability", Accounting Forum, Vol. 26 No. 2, pp. 152-171.

Patten, D.M. (2008), "Does the market value corporate philanthropy? Evidence from the response to the 2004 tsunami relief effort”, Journal of Business Ethics, Vol. 81 No. 3, pp. 599-607.

Pérez, A., García de los Salmones, M. del M. and López-Gutiérrez, C. (2015), "Corporate reputation in the Spanish context: An interaction between reporting to stakeholders and industry", Journal of Business Ethics, Vol. 129 No. 3, pp. 733746.

Pérez, A., López-Gutiérrez, C. and García de los Salmones, M. del M. (2017), “An empirical exploration of the link between reporting to stakeholders and corporate social responsibility reputation in the Spanish context", Accounting, Auditing \& Accountability Journal, Vol. 30 No. 3, pp. 668-698.

Perreault, W.D. and Leigh, L.E. (1989), "Reliability of nominal data based on qualitative judgments", Journal of Marketing Research, Vol. 26 No. 2, pp. 135148.

Peters, B.G. (2011), Institutional Theory in Political Science: The New Institutionalism, Bloomsbury Publishing USA, available at: https://books.google.es/books?hl=es\&lr=\&id=reKoAwAAQBAJ\&oi=fnd\&pg=PP1 $\& \mathrm{dq}=\% 22$ institutional + theory $+\mathrm{in}+$ political + science $:+$ The + new + institutionalism $\%$ 
22\&ots=QpU0ygzZim\&sig=UuVpcRjdD0KmSvqv17Sf9wemOfA.

Roberts, R.W. (1992), “Determinants of corporate social responsibility disclosure: An application of stakeholder theory", Accounting, Organizations and Society, Vol. 17 No. 6, pp. 595-612.

Shane, P.B. and Spicer, B.H. (1983), "Market response to environmental information produced outside the firm", The Accounting Review, Vol. 58 No. 3, pp. 521-538.

Skard, S. and Thorbjørnsen, H. (2014), "Is publicity always better than advertising? The role of brand reputation in communicating corporate social responsibility", Journal of Business Ethics, Vol. 124 No. 1, pp. 149-160.

Soppe, A., Schauten, M., Soppe, J. and Kaymak, U. (2011), “Corporate social responsibility reputation (CSRR): Do companies comply with their raised CSR expectations", Corporate Reputation Review, Vol. 14 No. 4, pp. 300-323.

Tang, L. (2012), "Media discourse of corporate social responsibility in China: A content analysis of newspapers", Asian Journal of Communication, Vol. 22 No. 3, pp. $270-288$.

Turker, D. (2009), “Measuring corporate social responsibility: A scale development study", Journal of Business Ethics, Vol. 85 No. 4, pp. 411-427.

Verbeeten, F.H.M., Gamerschlag, R. and Möller, K. (2016), “Are CSR disclosures relevant for investors? Empirical evidence from Germany", Management Decision, Vol. 54 No. 6, pp. 1359-1382.

Wang, A. (2007), "Priming, framing, and position on corporate social responsibility", Journal of Of Public Relations Research, Vol. 19 No. 2, pp. 123-145.

Wang, A. (2008), "Dimensions of corporate social responsibility and advertising practice", Corporate Reputation Review, Vol. 11 No. 2, pp. 155-168.

Wei, J., Wang, H., Fan, J. and Zhang, Y. (2013), “Corporate accidents, media coverage, 
and stock market responses: Empirical study of the Chinese listed firms", Chinese Management Studies, Vol. 7 No. 4, pp. 617-630.

Wright, P., Ferris, S.P., Hiller, J.S. and Kroll, M. (1995), “Competitiveness through management of diversity: Effects on stock price valuation", Academy of Management Journal, Vol. 38 No. 1, pp. 272-287.

Zhang, J. and Swanson, D. (2006), “Analysis of news media's representation of corporate social responsibility (CSR)", Public Relations Quarterly, Vol. 51 No. 2, pp. 13-17.

Zhang, L., Wang, T. and Fung, H. (2014), "Market reaction to corporate social responsibility announcements: Evidence from China", China \& World Economy, Vol. 22 No. 2, pp. 81-101.

\section{Appendix}

\section{Insert Table 4 about here}

\section{Insert Figure 1 about here}

The piece of news entitled "Iberdrola, Acciona and other 41 international companies join forces against climate change" describes the agreement letter that 43 CEOs have signed to reivindicate a global climate agreement at the Paris Summit 2015. Therefore, it refers to a CSR action of the company that is expected to have a positive impact on the community and a positive effect on the market value of the company. On the contrary, the piece of news entitled "Multa de 25 millones a Iberdrola por manipular el precio de la energía eléctrica" describes negative information concerning how the same company dealt with the prices of its products to customers, which is expected to have a negative 
impact on the market value of the company. More precisely, it discusses on the fine of 25 million euros that The National Commission on Markets and Competition (CNMC in Spanish) has imposed on Iberdrola for manipulating the price of electricity.

Based on the codification protocol that we created to select and classify CSR news for the study, these two headlines were coded as follows:

\section{Insert Table 5 about here}


Table 1: Caracterization of CSR news in the sample

\begin{tabular}{|c|c|c|c|c|c|c|c|c|}
\hline \multirow[b]{2}{*}{ Dimension } & \multirow[b]{2}{*}{ Topics } & \multirow[b]{2}{*}{+} & \multirow[b]{2}{*}{-} & \multicolumn{4}{|c|}{ Industry } & \multirow[b]{2}{*}{ Total } \\
\hline & & & & Basic & Energy & Finance & $\begin{array}{c}\text { Goods } \\
\& \\
\text { services }\end{array}$ & \\
\hline \multirow{5}{*}{$\begin{array}{l}\text { Community } \\
(n=63)\end{array}$} & Environmental policy, systems and performance & 16 & 1 & 6 & 9 & 2 & - & 17 \\
\hline & Social and charitable contribution & 11 & 1 & - & - & 12 & - & 12 \\
\hline & Educational and cultural contribution & 13 & - & 2 & 4 & 7 & - & 13 \\
\hline & Economic development programs & 19 & - & 1 & 5 & 8 & 5 & 19 \\
\hline & Other & 2 & - & - & - & - & 2 & 2 \\
\hline \multirow{7}{*}{$\begin{array}{l}\text { Customers } \\
(\mathrm{n}=\mathbf{5 8})\end{array}$} & Competitive prices and payment conditions & 7 & 4 & 2 & 4 & 4 & 1 & 11 \\
\hline & High product quality, health and safety & 4 & 2 & - & 2 & - & 4 & 6 \\
\hline & High innovation and accessibility & 6 & - & - & 4 & - & 2 & 6 \\
\hline & Development of products to meet the special needs of the disadvantaged & 17 & - & - & - & 15 & 2 & 17 \\
\hline & Standards, voluntary codes and transparency for marketing practices & - & 6 & - & - & 2 & 4 & 6 \\
\hline & Customer service, relations, communication and dialogue mechanisms & 6 & 3 & - & 1 & 8 & - & 9 \\
\hline & Other & 3 & - & 1 & - & 2 & - & 3 \\
\hline \multirow{2}{*}{$\begin{array}{l}\begin{array}{l}\text { Investors } \\
(\mathrm{n}=46)\end{array} \\
\end{array}$} & Investor rights & 39 & 2 & 9 & 9 & 15 & 8 & 41 \\
\hline & Other & 2 & 3 & 1 & 1 & 3 & - & 5 \\
\hline \multirow{5}{*}{$\begin{array}{l}\text { Employees } \\
(\mathbf{n}=28)\end{array}$} & Equal opportunities & - & 2 & - & - & 2 & - & 2 \\
\hline & Social benefits & 4 & - & - & 1 & 2 & 1 & 4 \\
\hline & Freedom of association, collective bargaining and complaint procedures & - & 2 & 2 & - & - & - & 2 \\
\hline & Job creation and stability & 6 & 10 & 1 & - & 7 & 8 & 16 \\
\hline & Other & 4 & - & 1 & 1 & 2 & - & 4 \\
\hline Total & & 159 & 36 & 26 & 41 & 91 & 37 & 195 \\
\hline
\end{tabular}


Table 2: Study 1 - Event study results

\begin{tabular}{|c|c|c|c|c|c|c|c|c|}
\hline \multirow{3}{*}{$\frac{\text { Event window }}{[-1,0]}$} & \multicolumn{3}{|c|}{$\begin{array}{c}\text { Positive news }(+) \\
n=159\end{array}$} & \multicolumn{3}{|c|}{$\begin{array}{c}\text { Negative news (-) } \\
n=36\end{array}$} & \multirow{2}{*}{\multicolumn{2}{|c|}{$\begin{array}{c}\text { Wilcoxon rank-sum test } \\
\mathrm{Z}\end{array}$}} \\
\hline & \multirow{2}{*}{$\begin{array}{c}\text { ACAR } \\
0.24 \%\end{array}$} & \multicolumn{2}{|c|}{ Dodd \& Warner } & \multirow{2}{*}{$\begin{array}{l}\text { ACAR } \\
-1.48 \%\end{array}$} & \multicolumn{2}{|c|}{ Dodd \& Warner } & & \\
\hline & & 2.24 & $* *$ & & -3.06 & $* * *$ & 69.79 & $* * *$ \\
\hline [0] & $0.23 \%$ & 2.56 & $* *$ & $-0.82 \%$ & -1.71 & $*$ & 73.21 & $* * *$ \\
\hline$[0,+1]$ & $0.49 \%$ & 3.24 & $* * *$ & $-2.09 \%$ & 3.97 & $* * *$ & 123.41 & $* * *$ \\
\hline$[-1,+1]$ & $0.51 \%$ & 3.00 & $* * *$ & $-2.75 \%$ & -4.75 & $* * *$ & 63.01 & $* * *$ \\
\hline$[-5,+5]$ & $-0.20 \%$ & -0.65 & & $0.88 \%$ & 0.58 & & 49.76 & $* * *$ \\
\hline
\end{tabular}

$* * *$ indicates a level of significance of $0.01, * *$ indicates a level of significance of $0.05, *$ indicates a level of significance of 0.10 
Table 3: Study 2 - Regression analysis results

\begin{tabular}{|c|c|c|c|c|}
\hline & Coefficient & t-statistic & & Beta \\
\hline $\operatorname{BAS}\left(\alpha_{1}\right)$ & -0.17 & -2.60 & $* * *$ & -1.77 \\
\hline SIG*BAS $\left(\varphi_{1}\right)$ & 0.21 & 3.06 & $* * *$ & 2.00 \\
\hline $\operatorname{ENER}\left(\alpha_{2}\right)$ & -0.32 & -4.47 & $* * *$ & -4.05 \\
\hline SIG*ENER $\left(\varphi_{2}\right)$ & 0.36 & 4.71 & $* * *$ & 4.40 \\
\hline FINANC $\left(\alpha_{3}\right)$ & -0.17 & -2.29 & $* *$ & -2.67 \\
\hline SIG*FINANC $\left(\varphi_{3}\right)$ & 0.22 & 2.72 & $* * *$ & 3.24 \\
\hline $\operatorname{GSER}\left(\alpha_{4}\right)$ & -0.18 & -2.52 & $* *$ & -2.18 \\
\hline SIG*GSER $\left(\varphi_{4}\right)$ & 0.22 & 2.88 & $* * *$ & 2.30 \\
\hline $\operatorname{SALES}\left(\alpha_{5}\right)$ & 0.01 & 2.11 & $* *$ & 0.37 \\
\hline SIG*SALES $\left(\varphi_{5}\right)$ & -0.01 & -2.49 & $* *$ & -2.15 \\
\hline $\operatorname{ROE}\left(\alpha_{6}\right)$ & 0.00 & 0.46 & & 0.04 \\
\hline SIG*ROE $\left(\varphi_{6}\right)$ & -0.01 & -0.78 & & -0.06 \\
\hline $\operatorname{PDCT}\left(\alpha_{7}\right)$ & 0.00 & 2.00 & $* *$ & 1.42 \\
\hline SIG*PDCT $\left(\varphi_{7}\right)$ & 0.00 & -2.05 & $* *$ & -1.49 \\
\hline$\alpha_{1}+\varphi_{1}$ & 0.04 & 1.82 & $*$ & 0.24 \\
\hline$\alpha_{2}+\varphi_{2}$ & 0.04 & 1.49 & & 0.36 \\
\hline$\alpha_{3}+\varphi_{3}$ & 0.04 & 1.75 & * & 0.58 \\
\hline$\alpha_{4}+\varphi_{4}$ & 0.04 & 1.52 & & 0.12 \\
\hline$\alpha_{5}+\varphi_{5}$ & 0.00 & -1.50 & & -1.78 \\
\hline$\alpha_{6}+\varphi_{6}$ & 0.00 & -0.71 & & -0.02 \\
\hline$\alpha_{7}+\varphi_{7}$ & 0.00 & -0.74 & & -0.07 \\
\hline $\mathrm{R}^{2}$ & 0.46 & & & \\
\hline $\mathrm{F}$ & 7.10 *** & & & \\
\hline
\end{tabular}


Table 4: Initial pull of CSR dimensions and topics

\begin{tabular}{|c|c|}
\hline Dimension & Topics \\
\hline Community & $\begin{array}{l}\text { Environmental policy, systems and performance } \\
\text { Social and charitable contribution } \\
\text { Educational and cultural contribution } \\
\text { Economic development programs } \\
\text { Human rights } \\
\text { Contribution to future generations } \\
\text { Having a foundation } \\
\text { Consultation with community leaders to know about emerging issues }\end{array}$ \\
\hline Customers & $\begin{array}{l}\text { Competitive prices and payment conditions } \\
\text { High product quality } \\
\text { High innovation and accessibility } \\
\text { Product health and safety } \\
\text { Development of products to meet the special needs of the disadvantaged } \\
\text { Confidentiality } \\
\text { Standards and voluntary codes for advertising and marketing practices } \\
\text { Transparency in advertising and marketing practices } \\
\text { Customer relations, communication and dialogue mechanisms } \\
\text { Regular evaluation of customer satisfaction } \\
\text { CSR actions in collaboration with customers }\end{array}$ \\
\hline Investors & $\begin{array}{l}\text { Investor rights and complaint procedures } \\
\text { Formal representation in decision-making } \\
\text { Investor relations, communication and dialogue mechanisms } \\
\text { Regulatory mechanisms for prohibiting insider trading } \\
\text { Rules to strengthen auditor independence } \\
\text { Provision of all required information to credit rating agencies }\end{array}$ \\
\hline Employees & $\begin{array}{l}\text { Training and development } \\
\text { Health and safety } \\
\text { Equal opportunities } \\
\text { Diversity } \\
\text { Reconciliation of work and family life } \\
\text { Social benefits } \\
\text { Freedom of association, collective bargaining and complaint procedures } \\
\text { Formal representation in decision-making } \\
\text { Employee relations, communication and dialogue mechanisms } \\
\text { Regular evaluation of employee satisfaction } \\
\text { Policy of remuneration, compensation and rewards } \\
\text { Job creation and stability }\end{array}$ \\
\hline Regulators & $\begin{array}{l}\text { Payment of taxes on a regular and continuing basis } \\
\text { Compliance with local laws and rgulations } \\
\text { Bribery and whistle-blowing programs } \\
\text { Description of policies to political lobbying and contributions }\end{array}$ \\
\hline Partners & $\begin{array}{l}\text { Policy to ensure ethical and friendly procurement at partner facilities } \\
\text { Policy on restrictions on the use of child labour, sweat shop and violation of human rights at partner facilities } \\
\text { Inspection of partners facilities for health, safety and environmental aspects } \\
\text { Policy for social accountability or sustainable reporting by partners } \\
\text { Equal opportunities when establishing alliances } \\
\text { Policy to pay and receive competitive market prices timely to/from partners } \\
\text { CSR actions in collaboration with partners }\end{array}$ \\
\hline Activists & $\begin{array}{l}\text { Employment volunteer activities and donation programs } \\
\text { Partnerships with nongovernmental and community organizations, government agencies and other industry groups dedicated } \\
\text { to CSR causes }\end{array}$ \\
\hline Media & $\begin{array}{l}\text { Regular publication of financial and non-financial information } \\
\text { Management of relationships with the media }\end{array}$ \\
\hline
\end{tabular}

Source: Pérez et al. (2015) 
Figure 1. Examples of positive and negative CSR news included in the sample

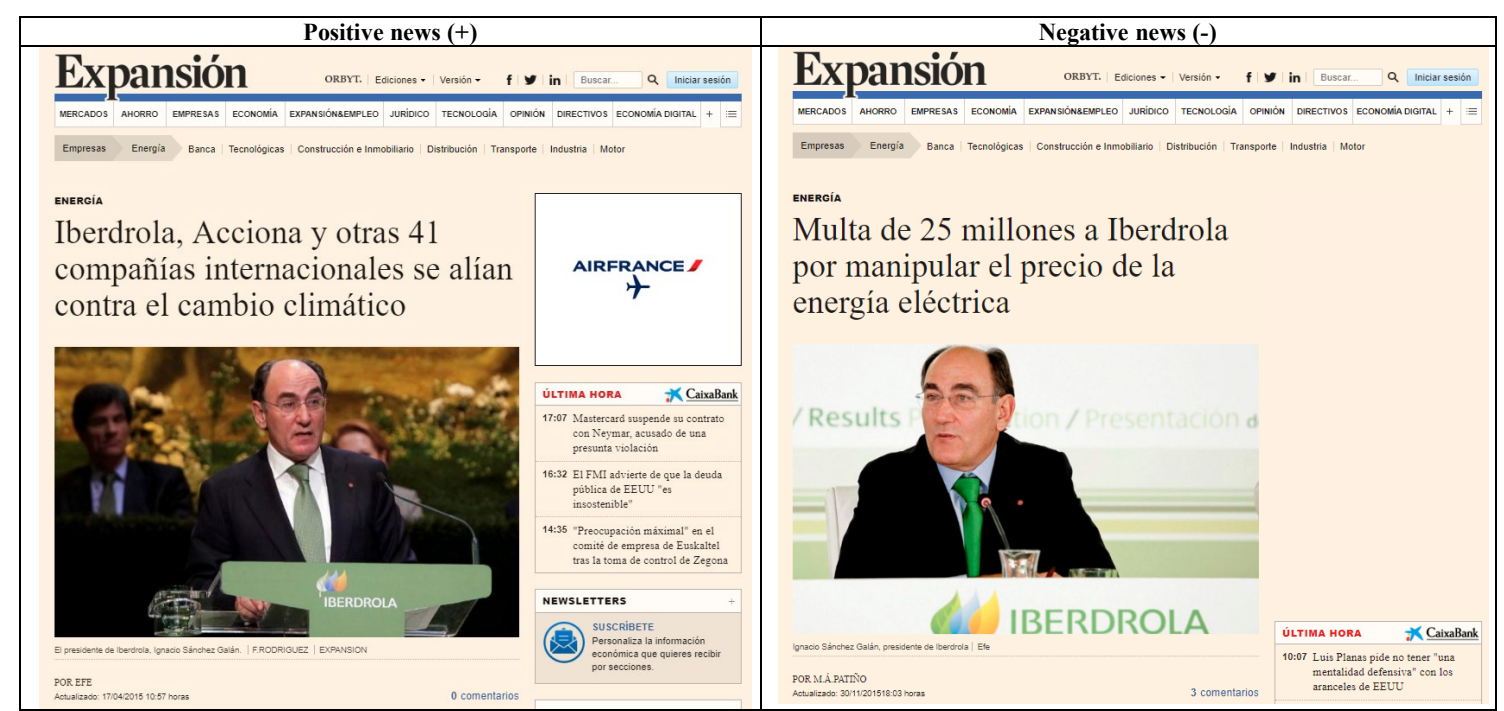


Table 5: Example of the codification procedure used to select and classify CSR news

\begin{tabular}{cccccc}
\hline Event date & Company & Industry & Dimension & Topic & $\begin{array}{c}\text { Overall } \\
\text { assesment }\end{array}$ \\
\hline $\mathbf{1 7 / 0 4 / 2 0 1 5}$ & $\begin{array}{c}\text { Iberdrola } \\
\text { (www.iberdrola.es) }\end{array}$ & $\begin{array}{c}\text { Energy } \\
\text { industry }\end{array}$ & $\begin{array}{c}\text { Community } \\
\text { (environment) }\end{array}$ & $\begin{array}{c}\text { Environmental policy, systems } \\
\text { and performance }\end{array}$ & Positive \\
\hline $\mathbf{3 0 / 1 1 / 2 0 1 5}$ & $\begin{array}{c}\text { Iberdrola } \\
\text { (www.iberdrola.es) }\end{array}$ & $\begin{array}{c}\text { Energy } \\
\text { industry }\end{array}$ & Customers & $\begin{array}{c}\text { Competitive prices and } \\
\text { payment conditions }\end{array}$ & Negative \\
\hline
\end{tabular}

